Nonproliferation Review

\title{
ACCEPTANCE AND ANXIETY
}

\section{Mustafa Kibaroglu}

To cite this article: Mustafa Kibaroglu (2011) ACCEPTANCE AND ANXIETY, Nonproliferation Review, 18:1, 201-217, DOI: 10.1080/10736700.2011.549181

To link to this article: https://doi.org/10.1080/10736700.2011.549181

曲 Published online: 19 Feb 2011.

Submit your article to this journal

Шll Article views: 255 
SPECIAL ISSUE

ACCEPTANCE AND ANXIETY

Turkey (Mostly) Embraces Obama's Nuclear

Posture

\section{Mustafa Kibaroglu}

US nuclear weapons have been an important part of Turkey's security strategy since their first deployment on Turkish soil in the early 1960s. Turkey's NATO membership and its close relationship with the United States have been perceived to be integral to maintaining its security. The release of the 2010 US Nuclear Posture Review (NPR), with its focus on disarmament and reduced reliance on nuclear weapons, has a number of potential consequences for Turkey. This article provides background on the history of Turkish-US nuclear weapons policy in light of issues ranging from Middle Eastern politics to the development of NATO's new Strategic Concept. It then describes how actors in the government, military, and academia in Turkey have reacted to the NPR, why they reacted as they did, and how the Obama administration's initiatives may be received in Turkey in the future. This article concludes that both military and civilian actors in Turkey have reacted favorably to the NPR and are pleased by its emphasis on nuclear nonproliferation and the maintenance of extended deterrence; however, there is less agreement in Turkey about the emphasis placed by the NPR on the danger of nuclear terrorism.

KEYWORDS: Turkey; United States; NATO; nuclear policy; nuclear weapons

The 2010 US Nuclear Posture Review (NPR) Report, published on April 6, 2010 by the Department of Defense, aims to provide a roadmap for the Obama administration to reduce nuclear risks to the United States and its allies. The document specifies five key objectives: preventing nuclear proliferation and nuclear terrorism; reducing the role of nuclear weapons in US national security; maintaining strategic deterrence and stability at reduced nuclear force levels; strengthening regional deterrence while reassuring US allies and partners; and sustaining a safe, secure, and effective nuclear arsenal. ${ }^{1}$

Turkey has a unique strategic relationship with the United States: an ally and a NATO member with US nuclear weapons on its soil, Turkey borders a number of Middle Eastern states that are or have been of proliferation concern. As a non-nuclear weapon state party to the Treaty on the Non-Proliferation of Nuclear Weapons (NPT), Turkey is seriously concerned about the future of the nuclear nonproliferation regime. As a long-standing member of NATO, Turkey's national security strategy relies heavily on the extended nuclear deterrence offered by the alliance. Understanding how Turkey has perceived and responded to the NPR will therefore be an important test of the influence of the Obama administration's policies. 
This article has two main parts. First, in order to provide background on the foreign and security policies that continue to influence Turkey's arms control discussions, it outlines the history of the deployment of US nuclear weapons on Turkey's soil and how the country's strategic environment and threat perceptions have changed since the Cold War. Second, this article explores the responses of various actors within Turkey's government, military, and academic institutions to the Obama administration's NPR, with particular attention paid to the country's role in the nonproliferation regime, its view of nuclear disarmament and extended deterrence, and its perspective on the threat of nuclear terrorism.

It should be noted at the outset that nuclear disarmament, nuclear proliferation, and nuclear terrorism do not figure prominently in public discourse in Turkey. In a country preoccupied with a multitude of domestic problems, the topics of nuclear disarmament and nonproliferation are often casualties of discussions of other more pressing developments. ${ }^{2}$ Proliferation-related issues are followed by only a handful of bureaucrats in various government offices, some members of the military, and a small cadre of academics, some of whom also serve as advisers to politicians. Views are quickly circulated, and it is not surprising to hear (or read) almost identical opinions from many different governmental sources. The military, meanwhile, is careful not to issue ad hoc commentaries on these matters, other than official statements from the Turkish General Staff. ${ }^{3}$ High-ranking military officers typically emphasize that their views do not necessarily represent the position of their institutions and that they speak only on the condition of not being attributed.

The media attention given to these issues in Turkey has grown, though generally only in response to major events like the April 2010 Nuclear Security Summit in Washington, DC. The summit received the attention it did in the Turkish media in part because Prime Minister Recep Tayyip Erdogan met there with President Barack Obama; little coverage was given to the summit's substance. Similarly, the signing of the New Strategic Arms Reduction Treaty on April 8, 2010 by President Obama and Russian President Dmitry Medvedev was covered in the Turkish press, albeit only superficially and perhaps only because of the popularity of the two leaders in Turkey. The release of the NPR, which took place only days before these other major events, captured even less attention, with only a few news channels offering commentary on how it would affect Turkey's security. ${ }^{4}$ Nuclear disarmament and nonproliferation thus remain very much on the outskirts of Turkish political discourse.

\section{Turkey and US Nuclear Weapons}

The decision to deploy US nuclear weapons in Turkey was made at the December 1957 NATO summit meeting held in Paris. Though US intermediate-range nuclear Jupiter missiles were first placed near Izmir in 1961, they were withdrawn by 1963 as part of a secret agreement between President John F. Kennedy and Soviet leader Nikita Khrushchev to resolve the Cuban Missile Crisis. ${ }^{5}$ This withdrawal did not, however, dramatically change the role that Turkey would play in the nuclear strategy of the United States or in NATO's 
contingency planning. The United States still sought to display NATO's solidarity with Turkey and to demonstrate the alliance's commitment to extended nuclear deterrence. ${ }^{6}$ In the early 1960s, US nuclear weapons deliverable by US and Turkish military aircraft were deployed at air bases in Ankara, Eskisehir, Balikesir, and Malatya, and squadrons of jet fighters were assigned to nuclear strike missions as part of NATO contingency plans. ${ }^{7}$ In addition, the Incirlik base near Adana was allocated to the United States for the stationing of nuclear-capable US bomber aircraft.

There were two main reasons for Turkey to host US nuclear weapons. First and foremost was their deterrent value against the nuclear and conventional capabilities of the Soviet Union. ${ }^{8}$ The Soviet Union considered Turkey's membership in NATO inimical to its regional interests and an open challenge to its security. In a November 1951 nota, the Soviets argued that the invitation of NATO membership extended to Turkey-a country that does not border the Atlantic Ocean-was an expression of the desire of Western powers to use Turkish territory to establish an aggressive front toward the Soviet Union. Turkey responded that if the Soviet Union could assess its own status and attitude, it would understand Turkey's reasons for concern. ${ }^{9}$ The Soviet threat only grew during the 1960 s and 1970s as the Russians closed the gap with the Americans in the nuclear field. The Soviet Union also increased its military presence across Turkey's eastern frontier and its naval presence in the Mediterranean, and it began military cooperation with Syria and Iraq. The growing Soviet military presence across the southern flank of NATO led the alliance, particularly Turkey, to increasingly rely on nuclear forces for security. ${ }^{10}$

A second reason for Turkey to host US nuclear weapons was NATO's burden-sharing principle: since the benefits of collective security are shared by all, the risks and burdens of the alliance should also be shared. Turkey has subscribed to this principle since it joined NATO in 1952. In fact, Turkey had already displayed its willingness to share the burden of defending the interests of the Western alliance by committing a significant number of troops to the Korean War in 1950, before NATO membership. ${ }^{11}$

Turkey continues to host US tactical nuclear weapons on its territory, albeit in much smaller numbers and at only one location, Incirlik Air Base on the eastern Mediterranean coast. ${ }^{12}$ All other nuclear weapons have been withdrawn. ${ }^{13}$ The Turkish Air Force no longer has any operational link with the remaining deployed tactical nuclear weapons. ${ }^{14}$ Even after the end of Cold War, Turkish military commanders believed US nuclear weapons constituted a credible deterrent against rivals in the Middle East, such as Iran, Iraq, and Syria, all of which are believed to have or have had unconventional weapons capabilities and delivery vehicles such as ballistic missiles. ${ }^{15}$ Although the threats facing Turkey have changed, Turkish officials continue to view the tactical nuclear weapons as important to the country's security interests and to Turkey's role in the NATO alliance.

\section{Turkey's Changing Strategic Environment and Threat Perception}

The end of the Cold War meant the literal disappearance of the threat to Turkey from the Soviet Union, causing drastic changes in Turkey's security environment. The Newly Independent States (NIS) emerged, and the most striking outcome of this development 
was that, for the first time in the four-century history of Turkish-Russian relations, Russia and Turkey were geographically separated. ${ }^{16}$ The minimum time required for Turkey's colossal ex-neighbor to launch a conventional surprise attack jumped from a figure once expressed in weeks, if not days, to one year. ${ }^{17}$ Although initially this improved Turkish security, changes to Russian military strategy in October 1993 (commensurate with the requirements of the so-called near-abroad doctrine) and Russia's related demands for revisions to the Conventional Armed Forces in Europe Treaty, gave rise to serious concerns in Ankara. ${ }^{18}$

Cooperation with Turkey remained important to US foreign policy for the region. In Central Asia and the Caucasus, Turkey was widely regarded by the Western community as a role model for the NIS. The possibility that Iran, whose fundamentalist regime was openly hostile to the West, would establish relations with these states alarmed Western capitals. Undermining Iran's potential expansionist ambitions became a top priority for Western nations, and Turkey, with its secular democracy and market economy, was considered a feasible role model for the NIS. ${ }^{19}$ Furthermore, the first Gulf War, resulting from Iraq's ambitions to become a regional hegemonic power, shook the foundations of regional relationships. ${ }^{20}$ With the Gulf War, ethnic conflict in the Caucasus, and secessionist violence in the former Yugoslavia, Turkey found itself surrounded by instability in almost every direction. The war in Iraq in 1991 resulted in the United States declaring a "no-fly zone" that complicated Turkey's security problems: the region became a sanctuary for Kurdistan Workers' Party (PKK) terrorists, who have waged a campaign against the central political authority in Turkey since 1984, and enabled them to increase their attacks on targets inside Turkey. (In 1991 the Turkish Grand National Assembly gave permission for US aircraft to use the Incirlik base to enforce the no-fly zone; that permission has been renewed every six months since.)

The September 11, 2001 attacks fundamentally changed US foreign and security policies within the Middle East, culminating in the 2003 US invasion of and war in Iraq. Relations between Turkey and the United States - now "neighbors" because of the heavy US military presence in Iraqi territory - took a turn for the worse, as characterized by tension in almost every area between the two "staunch" allies. One particularly divisive issue was the US no-fly zones - one above the 36th parallel in the Iraqi north, the other below the 32nd (later the 33rd) parallel in the Shiite south - that allowed the return of hundreds of thousands of Iraqi Kurds and were considered by many Turks as a first step in a US plan to create an independent Kurdish state. Despite US denials, Turkish generals and many like-minded politicians were very suspicious. The military, in particular, had witnessed the close coordination of US Special Forces and other US agents with the Iraqi Kurdish militia throughout the 1990s. ${ }^{21}$ Still, Ankara allowed the United States to use its air bases because it wanted to prevent a new wave of Iraqi refugees and because it felt it had implicit US approval to continue making sporadic cross-border incursions into northern Iraq, as it had been doing since the 1990 s. $^{22}$

Basing tens of thousands of troops on Turkish soil was considered a key part of US contingency planning in the 2003 Iraq war. However, during preliminary negotiations the three-party coalition in Turkey, led by Prime Minister Bülent Ecevit, was replaced by the single-party government of the Justice and Development Party (the AK Parti), which won 
two-thirds of the 550 seats in the Turkish Grand National Assembly. The new Turkish government resumed negotiations and drafted a motion that would allow US Special Forces to be deployed in Turkey; however, the motion was not approved. This forced the George W. Bush administration to resort to an alternative plan that relied heavily on militia-like units of the Kurdish forces (peshmergas) in northern Iraq, on the Kurdistan Democratic Party, and the Patriotic Union of Kurdistan. Turkey's decision not to cooperate militarily with the United States thus strained Turkish-US relations and strengthened the Kurds - a decidedly negative outcome from Turkey's perspective. ${ }^{23}$

Deterioration of the relationship between Ankara and Washington had an equally, if not more, negative impact on Turkish relations with Israel. Turkey and Israel enjoyed an almost perfect relationship throughout the 1990s. The 2003 war in Iraq, however, revealed the contradictory objectives of the two long-standing allies with respect to the future of Iraq. Turkey feared the emergence of an independent Kurdish state in northern Iraq, but that prospect seemed favorable for Israel's security given the threats posed by countries like Iran and Pakistan. ${ }^{24}$ The influence of Israel on the United States became the subject of intense political and public debate in Turkey in which Israel was often portrayed as masterminding the plans for the future of Iraq. ${ }^{25}$

Turkish authorities' misgivings concerning the true intentions of their US and Israeli counterparts with respect to shaping the future of the "greater Middle East" have been decisive in the improvement of Turkish relations with Syria and Iran. Furthermore, the basic philosophy of the AK Parti was highly conducive to improved relations with Middle Eastern neighbors. This new philosophy has become widely known as the "zero conflict with neighbors" school of thought, the brainchild of Professor Ahmet Davutoglu, later Turkey's foreign minister. ${ }^{26}$ The zero conflict policy adopted by the AK Parti government aimed to normalize relations among the members of the same family of nations in the region, which were deeply disturbed by the imperialist policies of the great powers. ${ }^{27}$ Russia, once a major rival, has become the single largest supplier of energy for Turkey, including oil, gas, and now nuclear.

\section{Turkish Reactions to the NPR}

Turkey's decades-old strategic alliance with the United States, and the presence of US nuclear weapons on Turkish territory, makes Turkey's reactions to the NPR all the more interesting. The Turkish government and the army are the two fundamental actors dealing with the challenges and threats posed to Turkey, in a broader context, while issues pertaining to national security are discussed at the highest level in National Security Council (NSC) meetings. The NSC does not have authority over the government to impose its decisions, and its discussions are not released to the public. ${ }^{28}$ That said, given the state tradition in Turkey, recommendations made by the NSC on military security issues have usually been accorded the utmost priority. Should there be a significant divergence of opinion between the government and the military with respect to national security issues, the NSC serves as a platform for the two major actors to resolve their differences, or, at least, make their opinion known to the other side. 
Because the US nuclear weapons stationed in Turkey constitute one of the most important aspects of Turkey's national security strategy, Turkish governments have usually followed long-established state policy. Most government officials believe that this state policy should not be subject to fluctuations based on short-term political goals or hasty decisions; hence, the government is pursuing essentially the same policy with respect to the status of US nuclear weapons in Turkey and has assigned more or less equal significance to the role that they play in maintaining national security. ${ }^{29}$ There are three areas in which it is particularly important to note the response - or lack of response - to the 2010 NPR in Turkey: 1) the issue of nuclear proliferation, which remains of the utmost concern to Turkey; 2) US disarmament plans and the future of extended deterrence; and 3) the priority ascribed to the threat of nuclear terrorism and nuclear proliferation. ${ }^{30}$

\section{Nuclear Nonproliferation: Understanding Turkish Behavior}

The Turkish government agrees with the NPR that nuclear proliferation is a "pressing threat." ${ }^{\prime 31}$ Turkey is a proud member of the NPT and has signed on to every international arrangement related to the nuclear nonproliferation regime, including the Nuclear Suppliers Group, the Zangger Committee, and the Additional Protocol of the International Atomic Energy Agency (IAEA). Turkey's official position can be summarized in the following statement made by the Turkish representative at the 2010 NPT Review Conference:

Turkey, like many others, regards the NPT as the cornerstone of the global nonproliferation regime and the essential foundation for the pursuit of nuclear disarmament. As a country that is party to all major international non-proliferation instruments and regimes, Turkey remains committed to the full implementation, further strengthening and universalization of the Treaty with all its three pillars - namely, non-proliferation, disarmament and peaceful uses of nuclear energy. The "grand bargain" on which the NPT regime is founded, rests upon these three inseparable and mutually reinforcing pillars. In this context, the importance of equal and balanced treatment of these three pillars cannot be overemphasized. ${ }^{32}$

Turkey faces severe regional nuclear proliferation concerns, as its security will be very much negatively affected by an Iranian nuclear weapons capability, if and when this develops. If Iran builds a nuclear weapons stockpile, it will add to its already militarily superior position among the Gulf states. The presence of nuclear weapons in the Iranian military arsenal will upset the delicate balance that has existed between the two nations since the Treaty of Kasr-i Shirin in 1639. The topographic and demographic characteristics of the region and the presence of more or less equal military capabilities on both sides have forced the parties to refrain from confronting each other. ${ }^{33}$ A nuclear-armed Iran would tip the balance of power in favor of Iran, threatening Turkish security.

From the US perspective, such concerns may make the May 2010 nuclear deal between Iran, Turkey, and Brazil (the Tehran Declaration) all the more puzzling. Logic suggests that no rational analyst in Turkey would remain indifferent, much less lend support, to Iran's nuclear weaponization. In addition to public statements, the Turkish vote 
on June 9, 2010 against UN Security Council Resolution 1929, which imposed further sanctions on Iran, also fueled speculation about Ankara turning away from the West and toward the Middle East. But this interpretation of Turkey's vote and the situation is simply wrong and is likely due to a lack of knowledge about the circumstances under which Turkey took this stance.

Prior to voting, Ertugrul Apakan, Turkey's ambassador to the United Nations, expressed the view that Turkey wished to see a restoration of international confidence in the exclusively peaceful nature of Iran's nuclear program. Seeing no viable alternative to a diplomatic and peaceful solution, Turkey signed the Tehran Declaration to provide nuclear fuel to the Tehran Nuclear Research Center. The agreement was designed as a confidencebuilding measure, which, if implemented, would contribute to the resolution of substantive issues relating to Iran's nuclear program in a positive, constructive atmosphere. In other words, Turkey viewed the Tehran Declaration as an important opportunity for diplomacy. Ankara was therefore deeply concerned that the adoption of sanctions would negatively affect the diplomatic process. Furthermore, Ambassador Apakan stressed that it was "rather unhelpful" that the responses of the Vienna Group had been received only a few hours before the vote. ${ }^{34}$ Apakan also underscored that Turkey's vote against the resolution should not be construed as indifference to the problems emanating from Iran's nuclear program, but rather to be encouraging Iran to be absolutely transparent about its nuclear program and to demonstrate full cooperation with IAEA in order to restore confidence. Turkey supported a diplomatic solution, but the sanctionsbased resolution was adopted. ${ }^{35}$ From the Turkish perspective, the Tehran Declaration did not contradict, but rather upheld, Turkey's commitment to the nuclear nonproliferation regime.

Some international security experts have gone so far as to express concern that Turkey may follow suit if and when Iran develops nuclear weapons. This and other similar views have been spelled out in various platforms ever since Turkey wanted to embark upon projects to build nuclear power plants in the 1970s. Neither its attempts in the 1970s nor subsequent nuclear energy efforts have come to fruition, for reasons ranging from the lack of a well-defined national energy strategy to domestic political problems. The most significant hurdle, however, has been Western countries' fear that Turkey might retransfer nuclear material and technology to other parties, primarily Pakistan. As a result, the United States has put pressure on supplier countries and firms to deny the export of nuclear reactors and related technology to Turkey. ${ }^{36}$ Ankara finally signed an agreement in May 2010 with Moscow to build its first nuclear power reactors.

In the face of the challenges and perceived threats from developments in the international arena, some individuals in Turkey do subscribe to the idea that the country should seek an independent nuclear weapons capability as a credible deterrent. ${ }^{37}$ These ambitions are unlikely to be realized, however, provided that some steps are taken by Turkey's friends and allies. In Turkey, there is much talk about why Ankara should develop nuclear weapons - at least among those who approach the issue from the perspectives of national pride and prestige, and security, too- but most decision makers are well aware that going nuclear would be a violation of Turkey's international obligations. State institutions, such as the Ministry of Foreign Affairs and the military, are keenly aware of 
these obligations and the costs of violating them. These entities have always formulated and conducted Turkey's foreign and security policies in line with Ataturk's dictum: peace at home, peace in the world. Against this backdrop, one should not expect Turkey to embark upon a hasty nuclear weapons program, even if Iran crosses the critical threshold.

Should Iran go nuclear, however, what will keep Turkey from following suit will not simply be responsible state practice. The extent to which Turkey's allies are willing and able to allay its regional security fears will have a decisive effect on Turkish policy makers. Improving relations with the United States and the European Union, as well as strengthening the nuclear nonproliferation regime, will make the greatest impact in this regard. ${ }^{38}$ Turkey considers the success of the nuclear nonproliferation regime deeply important to its security, and it goes without saying that the United States - with its political, economic, and military might - is one of the countries with the greatest impact on the future of the regime by way of the steps taken (or not) in the areas of nuclear disarmament, entry into force of the Comprehensive Nuclear-Test-Ban Treaty (CTBT), and concluding a Fissile Material Cutoff Treaty at an early date.

\section{Nuclear Disarmament and Extended Deterrence: Turkey's View on Maintaining Security}

The 2010 NPR sought to reassure allies while promoting disarmament, a particularly difficult task when it comes to Turkey, which still considers US nuclear weapons on its soil important to its security and its role in NATO. Nevertheless, Turkey had a generally positive response to both the NPR's focus on disarmament and its commitment to maintaining a credible extended deterrent to allies, even as the United States reduces its nuclear arsenal. Two areas regarding the future of extended deterrence cause particular concern in Turkey, however: the continuation (at least for the foreseeable future) of the deployment of tactical nuclear weapons in NATO countries; and the architecture and development of a possible NATO ballistic missile defense project.

A joint working paper co-sponsored by Turkey (and a number of European allies) and submitted to the May 2010 NPT Review Conference stated:

Nuclear disarmament requires an incremental but sustained approach in which all Treatybased nuclear arms control and disarmament agreements play distinctive roles. Treatybased nuclear arms control is indispensable for the active promotion of collective security and cooperation in the pursuit of global disarmament. The unequivocal undertaking by all nuclear-weapons States to accomplish the total elimination of their nuclear arsenals leading to nuclear disarmament, to which all States parties are committed under Article VI of the Treaty, is one of the major achievements of the Treaty process. This undertaking must now become operational, building also on Article $\mathrm{VI}$ and the 13 practical steps for nuclear disarmament agreed upon in $2000{ }^{39}$

With respect to Article VI of the NPT, Turkish government officials emphasize that "unequivocal commitments of the nuclear-weapons States parties to the Treaty should not be forgotten." ${ }^{40}$ While acknowledging that a significant number of nuclear weapons have been dismantled since the end of the Cold War, Turkish government officials also believe 
that "at present, nuclear disarmament efforts seem to be limited to only two nations, namely the U.S. and Russia, and even then, the numbers involved in the reductions are not fully satisfactory." ${ }^{\prime 1}$ For that reason, Turkish officials maintain that "on the one hand, the U.S. and Russia must hold further disarmament negotiations aimed at further reducing their nuclear arsenals, including non-strategic nuclear weapons; and on the other hand, other nuclear weapons states, such as United Kingdom, France, and China must also commit themselves for further cuts in their nuclear arsenals, paving the way toward their elimination." ${ }^{42}$ In the same vein, officials also argue that they "don't even know how many nuclear weapons these states have, and while there is no progress in the direction of reduction of their arsenals, there is also talk of new weapons designs in these countries"referring specifically to the United Kingdom, France, and China. ${ }^{43}$

Turkey's interpretation of another key objective of the 2010 NPR - "strengthening regional deterrence and reassuring its allies and partners" - is very positive. Even in the absence of an imminent nuclear threat to Turkey's security, the view among both civilian and military Turkish security elites does not seem to have changed since the Cold War. One explanation for the uniformity of their views lies in the prestige attributed to nuclear weapons. There are specific reasons that explain why Turkish government officials and civilian and military bureaucrats want to retain US nuclear weapons on Turkey's soil, first and foremost being the perceived threat from the still uncertain international security environment. Turkish government officials' views were expressed (in not-for-attribution notes) as follows:

Nuclear weapons continue to preserve their critical importance for the security of the [North Atlantic] alliance, yet they are regarded more as political weapons. Our country is committed to the vision of a world free of nuclear weapons, and thus we support every effort in that direction.... Nevertheless, it must be acknowledged that attaining such a goal will not be possible any time soon, and that more time and patience will be needed to realize this objective. Hence, so long as these weapons do still exist in other parts of the world, it is indispensible for NATO to preserve a safe, secure, and effective nuclear arsenal that will be capable of deterring all sorts of enemies in order to ensure the security of all of its allies.... [In NATO's new Strategic Concept] our country will want to see an explicit confirmation of the commitment [of the alliance] to the preservation of an effective and credible deterrent by way of maintaining a combination of conventional and nuclear weapons capability. In addition to that, our determination for the preservation of the transatlantic link and solidarity as well as fair risk and burden sharing to continue to constitute the fundamental principles of the nuclear strategy of the alliance will persist. ${ }^{44}$

The above quote emphasizes that while Turkey supports nuclear disarmament, in the foreseeable future it wants to maintain nuclear weapons on its soil for both security and political reasons. Turkish officials still see the deployment of US nuclear weapons in Turkey as part of the "burden sharing" principle within the alliance. They would prefer that other US allies also continue to host US nuclear weapons on their soil, if only in symbolic numbers; that way, Turkey will not stand out as the only country in NATO that retains US nuclear weapons in Europe. ${ }^{45}$ It was reported in 2005 that there were some 480 tactical US 
nuclear weapons (gravity bombs) that were deployed at eight bases in six NATO countries. ${ }^{46}$ This figure has come down to a level around 200 in more recent reports. ${ }^{47}$

Another fundamental reason why Turkish officials want to keep these weapons has to do with the nature of Turkish-US relations and Turkey's place in the Western alliance. Turkish-US bonds were severely strained during and after Turkey's rejection of the US request to station troops on its soil. Many feared that withdrawing US nuclear weapons from Turkey in the aftermath of such a delicate period would further weaken the longstanding strategic alliance (or the "partnership," as many Turkish and American analysts would prefer to call it). ${ }^{48}$ Though the relationship has improved since then, Turkish-US relations have not regained the momentum that existed prior to the 2003 crisis.

Turkish officials also express concern about the true desires of US administrations. They worry that the United States might have secretly developed, or be in the process of developing, new weapons systems that would not necessitate Europe-based nuclear deployments in support of NATO. Should this be the case, Turkish officials fear that the solidarity principle may be seriously hurt and the alliance might lose its spirit and its raison d'être. $^{49}$

If nuclear disarmament moves forward, the NPR emphasizes that ballistic missile defense will be an important part of maintaining extended deterrence. Turkey is essentially caught between its relationship with the United States and NATO (who are encouraging it to participate in a NATO ballistic missile defense project) and its good relations with Iran and Russia. The international media coverage of the NATO Meeting of Foreign and Defense Ministers in Brussels on October 14, 2010 might suggest that Turkey and other NATO members are having a row over the development of a ballistic missile defense project for the alliance. It is true that Turkey and the leading members of the alliance do not see eye to eye on every single aspect of the missile defense project of NATO; however, the degree of divergence of opinion is not as wide as it might seem from a distance.

The missile defense issue has been on the negotiating table with US authorities since the second term of President Bill Clinton. As previously discussed, Turkey's political and strategic environment was significantly different then, and Turkish authorities were more than willing to deploy air defense systems in Turkey, especially in regions neighboring the Middle East. Despite extended negotiations, no consensus could be reached. In the late 1990s, Turkey wanted to have a share in the development of ballistic missile defense technology - an idea not supported in the United States. A similar situation arose in the triangular relations between Turkey, the United States, and Israel over cooperation on the development and the eventual deployment of the Arrow-II air defense system. While Americans blame the Israelis for not wanting to share this technology with Turkey, Israelis pronounced almost exactly the same views about the attitude of their US counterparts. ${ }^{50}$ The joint project was shelved, and has not been resumed due to the deterioration of Turkish-Israeli relations.

Today, Turkey is still willing to be a partner in the missile defense project, provided that a number of issues are taken into consideration by the rest of the alliance. First and foremost, Turkey wants to see the project be a NATO project, rather than a US one. Turkey does not want a repeat of the post-Cuban Missile Crisis removal of the Jupiter missiles, where the United States had essentially unilateral control. Moreover, Turkey has doubts as 
to whether the US system would be aimed at protecting Turkey, or whether Israel's security would be its true concern. Second, Turkey does not want any country named as the source of the threat against which the alliance would be developing the project. ${ }^{51}$ Turkey's unwillingness to specifically name a state has two motives: it is reluctant to identify a neighboring country as a target, and it is concerned that Iran will exploit this to justify advancement of its own missile and military capabilities for defense purposes to the greater Islamic world and also elsewhere. Therefore, Turkey's opposition to naming a country is a calculated decision designed to halt Iran's growing missile capabilities. This point seems to be overlooked by many amid unfounded concerns that Turkey's loyalties are drifting away from the West and closer to Iran. A third condition is that every single square inch of the Turkish territory must be covered by the missile defense system once it becomes operational. ${ }^{52}$

Turkey is concerned about the future of extended deterrence, and would for the foreseeable future like to keep US tactical weapons in NATO countries, but it still supports the United States taking practical measures toward disarmament in the near future, namely through the ratification of the CTBT and the commencement of negotiations on a Fissile Material Cutoff Treaty. On the issue of nuclear test ban, the NPR stated that ratification of the CTBT "is central to leading other nuclear weapons states toward a world of diminished reliance on nuclear weapons, reduced nuclear competition, and eventual nuclear disarmament. US ratification could also encourage ratification by other states, including China, and provide incentives for the remaining states to work toward entry into force of the treaty." ${ }^{53}$ Not surprisingly, Turkish officials express their expectation that "this time the U.S. Congress should ratify the CTBT," and they also argue that "this is indeed a moral obligation of the United States." ${ }^{54}$ The Turkish government's support for the CTBT is also made explicit in the co-sponsored 2010 NPT Review Conference working paper, which emphasized that the entry into force of the CTBT "will form an integral part of a strengthened and more credible non-proliferation regime... [and] all States which have not yet done so swiftly sign and ratify the Treaty." ${ }^{\prime 55}$

Similarly, with respect to the issue of putting an end to the production of highly enriched uranium and plutonium, Turkish government officials are of the view that "commencement of negotiations on a verifiable Fissile Material Cutoff Treaty (FMCT) to halt the production of fissile material for use in nuclear weapons" is extremely important. ${ }^{56}$ An equal emphasis was placed on the issue in Turkey's co-sponsored working paper: "Commencing without any further procedural delay negotiations on an internationally and effectively verifiable fissile material cut-off treaty, and reaching agreement on such a treaty will offer a vital contribution to the global non-proliferation architecture. Pending such an agreement, we call for an immediate moratorium on the production of fissile material for nuclear weapons." 57

\section{Nuclear Terrorism: A Divergence of Views}

For the most part, military and government officials and academics in Turkey agree with the Obama administration about threats as described in the NPR; however, this is not the case with respect to the primacy the NPR assigned to the "threat of nuclear terrorism," 
despite the fact that addressing terrorism has been one of the highest priorities of Turkish governments for decades. The disagreement is not about the need to fight terrorism, but rather over the credibility of the threat posed by "nuclear terrorism."

Officially, the Turkish government does acknowledge the priority and urgency that the NPR placed on the "threat of nuclear terrorism." In his address to the 2010 NPT Review Conference, the Turkish representative noted the following:

The risk of acquisition of weapons of mass destruction and their means of delivery by terrorists and other non-state actors should not be underestimated either. We need to remain vigilant to cooperate to avoid possible attacks involving nuclear and radiological material. In this regard, the first and foremost step towards eliminating the risk of nuclear terrorism is to further the nuclear disarmament efforts and to decrease the role of nuclear weapons in national security policies. I hereby would like to note the balanced and carefully crafted outcome of the 2010 Nuclear Security Summit held last month which demonstrated the common determination in the field of nuclear security. The international community needs to redouble its efforts aimed at effective and universal implementation of all legal means available, including UNSC resolutions 1540 and 1887 and the Proliferation Security Initiative. ${ }^{58}$

Similarly, the Turkish Ministry of Foreign Affairs has stated:

Easy access to [weapons of mass destruction] through trafficking and willingness of some states to cooperate with terrorist, extremist or organized crime groups increase the concern that such weapons might end up in illegal hands. In the light of the threatening dimension of terrorism and the proliferation of weapons of mass destruction, Turkey sincerely desires to see that all countries will come to share the goals of non-proliferation and collectively work towards a safer and more stable world. ${ }^{59}$

The Turkish government's co-sponsored 2010 NPT Review Conference working paper referred to the necessity of dealing with the threat of WMD terrorism. On this particular issue the working paper stated: "Nuclear terrorism and illicit trafficking in nuclear material represent considerable security threats that need to be adequately addressed also at the international level. We recall that a key objective of Security Council resolution 1540 (2004) is to prevent non-state actors from acquiring nuclear weapons as well as relevant nuclear materials and technologies." ${ }^{60}$

The working paper also referred to the Nuclear Security Summit held in Washington, DC, in April 2010: "We welcome the Nuclear Security Summit and the adoption of the Communiqué and Work Plan, and support the overall objective to secure all vulnerable nuclear material within four years." ${ }^{\prime \prime 1}$ Turkey was one of the forty-six countries that were invited to the Nuclear Security Summit, and Prime Minister Erdogan attended the two-day summit; these actions can be considered as powerful indicators of Turkey's official stance vis-à-vis the threat of nuclear terrorism.

Many Turkish civilian and military bureaucrats and experts, however, do not necessarily share the US government's view that "the most immediate and extreme threat today is nuclear terrorism. ${ }^{\prime \prime 2}$ Turkey has suffered from terrorism of various kinds for nearly four decades; approximately 40,000 Turkish citizens have lost their lives, and 
hundreds of thousands have been injured. Turkey has been exposed to various types of terrorism, from the ultra-nationalist terrorism committed by the Armenian Secret Army for the Liberation of Armenia (ASALA), to ideological terrorism committed by Marxist-Leninist terrorist factions like the Revolutionary People's Liberation Party-Front, to the ethnic separatist PKK, to the so-called "radical Islamist" groups like Turkish Hezbollah and the Great Eastern Islamic Raider's Front. ${ }^{63}$

These types of terrorism are believed to pose the real threat to Turkish security, whereas nuclear terrorism is considered hype - if not a fantasy. Civilian and military bureaucrats and experts in Turkey do not believe that terrorist organizations are capable of acquiring or developing nuclear weapons today or in the foreseeable future. Consequently, when asked why US authorities consistently rank this issue as one of the gravest threats posed to US national security, Turkish officials almost unanimously express the view that, "the US administration wants to create an impression that the world is an extremely dangerous place and that other countries would be better off if they follow the lead of the United States in matters pertaining to international security." ${ }^{\prime 64}$

Another reason behind this divergence of opinion is the disappointment of Turkish government officials with the degree of support that Washington has given Turkey's fight against PKK terrorism. Turkey expected much more substantial aid from the United States in its fight against the terrorist organization, which is known to use US-controlled northern Iraqi territory as a safe haven for sustaining its armed struggle against Turkey. Hence, the prevailing view among the Turkish civilian and military officials in the lower ranks is that, "If my terrorist threat does not matter for the United States, why should I care about the terrorist threat to the United States [i.e., nuclear terrorism], which is hypothetical and exaggerated anyway?" 65

That said, contingencies involving WMD terrorist attacks are acknowledged by prominent scholars around the world as "low probability, high consequence" scenarios. ${ }^{66}$ So, conventional wisdom suggests that there is reason to worry about such a possibility. ${ }^{67}$ Considering that threat is a combination of intentions and capabilities, and that the leaders of various terrorist organizations have declared their intention to acquire and/or develop WMD, it seems reasonable to believe that if they do acquire such weapons, they will not hesitate to use them. Given this, it is absolutely necessary to take concerted action against terrorist organizations by collaborating and cooperating internationally on a wide array of issues. The divergence of opinion between US and Turkish security elites about the importance of "nuclear terrorism" should not interrupt cooperation between them. Instead, Turkey and the United States should commit to working through these differences by conducting more frequent consultations between high-ranking officials to discuss one another's concerns and priorities and organize a cooperative action plan in the fight against terrorism in the region.

\section{Conclusions}

In its broadest context, the 2010 Nuclear Posture Review was generally positively received by the Turkish security elite, in that the review makes policy recommendations on a host 
of nuclear security issues that are compatible with Turkey's grand strategic interests. For Turkey, a country that has never sought to develop nuclear weapons, enhancing the nuclear nonproliferation regime is becoming more and more of a priority. The region surrounding Turkey is associated with the proliferation of various weapons of mass destruction, which constitutes a serious threat to national security. Moreover, Iran's evolving nuclear program creates a multitude of problems that seriously worry Turkey's top security elites, including government officials, military experts, and academics. ${ }^{68}$ The importance of extended deterrence for Turkey is underscored by these and other international and regional developments.

Hence, with regard to maintaining strategic deterrence and stability at reduced nuclear force levels, while strengthening regional deterrence and reassuring US allies and partners, as well as sustaining safe, secure and effective nuclear arsenal, the Turkish and US approaches could not be more compatible. This is one particular area where Turkish civilian and military officials speak with one voice. Turkey wants the continuation of NATO's extended nuclear deterrence, and Turkish officials are glad to see that the Obama administration is not rushing to withdraw its remaining tactical nuclear weapons from Europe. Yet other views have emerged from within Turkish government circles occasionally suggesting that drawing down the US tactical nuclear arsenal might not be out of the question from Turkey's perspective. ${ }^{69}$ However, the prevailing view among the Turkish military officials, diplomats, and other civilian officials is that "it would be premature to even consider such a possibility now." ${ }^{70}$ All in all, it can be said that the 2010 NPR, perhaps carefully examined by not more than a handful of Turkish experts and officials, was warmly received in Turkey.

\section{NOTES}

1. Department of Defense, "Nuclear Posture Review Report" (hereafter 2010 NPR) April 6, 2010, p. iii, $<$ www.defense.gov/npr/docs/2010\%20nuclear\%20posture\%20review\%20report.pdf $>$.

2. As rare examples of studies conducted in Turkey on nuclear proliferation matters (other than those of the author), see Duygu B. Sezer, "Turkey's New Security Environment, Nuclear Weapons and Proliferation," Comparative Strategy 14 (1995), pp. 149-73; Sebnem Udum, "Turkey's Non-Nuclear Weapon Status: A Theoretical Assessment," Journal on Science and World Affairs 3 (2007), pp. 57-65; and Sinan Ulgen, "Preventing the Proliferation of Weapons of Mass Destruction: What Role for Turkey?" Center for Economics and Foreign Policy Studies, Discussion Paper Series, No. 2010/2, June 2010.

3. The official website of the Turkish General Staff is accessible at <www.tsk.tr $>$.

4. For Turkish media pieces on the NPR, see Fikret Ertan, "Obama'nin Nukleer Stratejisi: Olumlu Adim" [Obama's nuclear strategy: a positive step], Zaman Online, April 8, 2010, <www.zaman.com.tr/ yazar.do?yazino $=970659>$. The title of the article is self-explanatory regarding the views of the author on the subject. For an earlier assessment of the NPR, see "Obama Faces Reality Test on US Nuclear Posture," Agence-France Presse, February 21, 2010, <www.hurriyetdailynews.com/ n.php? $\mathrm{n}=$ obama-faces-reality-test-on-us-nuclear-posture-2010-02-21>. The 2010 NPR was also the subject of a think tank news item, although it only highlighted the main points of the review, rather than making any comments about its impact on Turkey: see Özlem Pinar Oran, "Obama'nin Yeni Nükleer Stratejisi" [Obama's new nuclear strategy], Stratejik Dusunce Enstitusu [Institute of Strategic Thinking], April 13, 2010, <www.sde.org.tr/tr/haberler/965/obamanin-yeni-nukleer-stratejisi.aspx> .

5. Nur Bilge Criss, "Strategic Nuclear Missiles in Turkey: The Jupiter Affair (1959-1963)," Journal of Strategic Studies 20 (1997), pp. 97-122. 
6. Mustafa Kibaroglu, "Turkey and Shared Responsibilities," in Scott Sagan, ed., Shared Responsibilities for Nuclear Disarmament (Cambridge, MA: American Academy of Arts and Sciences, 2010), p. 25.

7. General Ergin Celasin (ret.), former commander of the Turkish Air Force (1999-2001), recalls flying with these jet fighters in the early 1960s when he was at the rank of lieutenant. Author's interview with General Celasin, February 15, 2010, Ankara.

8. Mustafa Kibaroglu, "Reassessing the Role of U.S. Nuclear Weapons in Turkey," Arms Control Today, June 2010, p. 11, <www.armscontrol.org/act/2010_06/Kibaroglu >.

9. Mustafa Kibaroglu and Aysegul Kibaroglu, Global Security Watch-Turkey: A Reference Handbook (Westport, CT: Praeger Security International, 2009), p. 49.

10. Mustafa Kibaroglu, "Turkey," in Harald Müller, ed., Europe and Nuclear Disarmament: Debates and Political Attitudes in 16 European Countries (Brussels: European Interuniversity Press, 1998), p. 170.

11. Kibaroglu, "Reassessing the Role of U.S. Nuclear Weapons in Turkey," p. 11.

12. Hans M. Kristensen, US Nuclear Weapons in Europe: A Review of Post-Cold War Policy, Force Levels, and War Planning (Washington, DC: Natural Resources Defense Council, 2005), p. 9.

13. Mustafa Kibaroglu, "Isn't It Time to Say Farewell to US Nukes in Turkey?" European Security 14 (December 2005), pp. 443-57.

14. Author's interview with General Celasin, February 15, 2010, Ankara.

15. Kibaroglu, "Reassessing the Role of U.S. Nuclear Weapons in Turkey," p. 11.

16. If one excludes the rather distant neighborhood across the Black Sea.

17. Author's interviews with Turkish military experts, Ankara, 1996. Names withheld because the conversations were not on the record.

18. Mustafa Kibaroglu, "Turkey," pp. 164-65.

19. Ibid., pp. $165-66$.

20. Kibaroglu and Kibaroglu, Global Security Watch-Turkey.

21. Mustafa Kibaroglu, "Turkey Says No," Bulletin of the Atomic Scientists, July/August 2003, pp. $22-25$.

22. Ibid., p. 23.

23. Mustafa Kibaroglu, "Clash of Interest Over Northern Iraq Drives Turkish-Israeli Alliance to a Crossroads," Middle East Journal 59 (Spring 2005), pp. 246-64.

24. Ibid., p. 246.

25. Ibid., p. 249.

26. Mustafa Kibaroglu, "No Short-Term Fix to Relations," Bitterlemons-International: Middle East Roundtable 8 (June 2010), <www.bitterlemons-international.org/inside.php?id =1275>.

27. Author's recollection from his conversation with Professor Ahmet Davutoglu during a one-day workshop convened in Vienna, Austria, October 20, 2008.

28. Until about 2005, the NSC meetings were the most topical agenda item in Turkish politics. The council used to meet on the last working day of every month, and speculation about the content of the resolutions issued by its General Secretariat dominated public discussions, especially in times of heightened political debate about issues relating to the regime's secular character. Governments were expected by the military side of the NSC to ascribe utmost urgency to its "recommendations." The famous NSC resolution of February 28, 1997, also known as the "post-modern coup" of the military, paved the way to dissolution of the then one-year-old coalition government that was formed by the center-right Dogru Yol Partisi (True Path Party) under the leadership of Tansu Ciller and the "Islamist" Refah Partisi (Welfare Party) under the leadership and premiership of Necmettin Erbakan. With the democratization process gaining deeper and wider ground in Turkey over the last several years, especially since the start of accession negotiations with the European Union in 2005, the traditional role of the military in Turkish politics has much diminished. Today, NSC meetings are hardly mentioned in the press, unless there is an extraordinary event in national security arena that captures public attention.

29. Author's interviews with Turkish government officials, including advisers of top executives, Ankara, June and July 2010. Names withheld by request.

30. Author's interviews with Turkish government officials, Ankara, June and July 2010. Names withheld by request.

31. 2010 NPR, p. iv. 
32. "Statement by H.E. Ambassador Feridun Sinirlioglu," Ministry of Foreign Affairs of Turkey, 2010 NPT Review Conference, New York, May 6, 2010, p. 1, <www.un.org/en/conf/npt/2010/statements/pdf/ turkey_en.pdf $>$.

33. Mustafa Kibaroglu and Baris Caglar, "Implications of a Nuclear Iran for Turkey," Middle East Policy 15 (Winter 2008), p. 59.

34. The Vienna Group, which consists of the United States, Russia, and France in coordination with the IAEA, was supposed to provide the Tehran Research Reactor with 120 kilograms (kg) of 20 percent enriched uranium, in return for Iran's acceptance of storing in Turkey 1,200 kg of its low-enriched uranium stocks for one year, in accordance with the "swap deal" that was reached in Tehran between Turkey, Brazil, and Iran on May 17, 2010.

35. United Nations, "Security Council Imposes Additional Sanctions on Iran, Voting 12 in Favor to 2 Against, With 1 Abstention," SC/9948, UN Department of Public Information, News and Media Division, New York, June 9, 2010, <www.un.org/News/Press/docs/2010/sc9948.doc.htm>.

36. Mustafa Kibaroglu, "Turkey's Quest for Peaceful Nuclear Power," Nonproliferation Review 4 (SpringSummer 1997), p. 33.

37. For more on this issue, see Kibaroglu and Caglar, "Implications of a Nuclear Iran for Turkey," pp. 69-72.

38. Ibid., pp. $72-73$.

39. "Working Paper Submitted by Belgium, Lithuania, the Netherlands, Norway, Poland, Spain and Turkey for Consideration at the 2010 Review Conference of the States Parties to the Treaty on the NonProliferation of Nuclear Weapons," NPT/CONF.2010/WP.69, New York, May 11, 2010, p. 3, $<$ www.reachingcriticalwill.org/legal/npt/revcon2010/papers/WP69.pdf $>$.

40. Author's interviews with high-ranking diplomats from the Turkish Ministry of Foreign Affairs, Ankara, July 2010.

41. Ibid.

42. Ibid.

43. Ibid.

44. Written notes on the 2010 US NPR (in Turkish), given to the author upon his request by officials from various branches of the government, July 2010, Ankara. Name of the note taker withheld by request.

45. Views expressed by Ambassador Tacan Ildem, director general, International Security Affairs Department, Turkish Ministry of Foreign Affairs, during a one-day workshop convened in Ankara by the Foreign Policy Institute, June 4, 2010. For proceedings of the meeting, see "NATO's New Strategic Concept Conference June 2010, Ankara," Dis Politika/Foreign Policy 36 (Autumn 2010), pp. 9-12.

46. Kristensen, U.S. Nuclear Weapons in Europe, p. 9.

47. Mustafa Kibaroglu, "The Future of Extended Deterrence: The Case of Turkey," in Bruno Tertrais, ed., Perspectives on Extended Deterrence (Paris: Fondation pour la Recherche Stratégique, 2010), p. 92.

48. Ibid.

49. Ibid., pp. 92-93.

50. Author's recollection from his conversations with US and Israeli diplomats and military personnel in the early 2000s on various occasions.

51. Tulay Karadeniz, "Turkey Says Anti-Missile Should Not Single out Iran," Reuters, October 18, 2010, $<$ www.reuters.com/article/idUSTRE69H3BX20101018>.

52. View expressed by a high-level Turkish diplomat during an international workshop in Ankara, October 4, 2010.

53. 2010 NPR, p. 13.

54. Author's interview with high-ranking Turkish diplomats, Ankara, July 2010. Names withheld by request.

55. "Working Paper Submitted by Belgium, Lithuania, the Netherlands, Norway, Poland, Spain and Turkey for Consideration at the 2010 Review Conference of the States Parties to the Treaty on the NonProliferation of Nuclear Weapons," p. 4.

56. 2010 NPR, p. 13.

57. “Working Paper Submitted by Belgium, Lithuania, the Netherlands, Norway, Poland, Spain and Turkey for Consideration at the 2010 Review Conference of the States Parties to the Treaty on the NonProliferation of Nuclear Weapons," p. 4. 
58. Statement by H.E. Ambassador Feridun Sinirlioglu, Undersecretary of the Ministry of Foreign Affairs of the Republic of Turkey, at the 2010 Review Conference of the States Parties to the Treaty on the NonProliferation of Nuclear Weapons, New York, May 6, 2010, p. 2

59. "Turkey's Approach to Arms Control and Disarmament," Ministry of Foreign Affairs of Turkey, undated, $<$ www.mfa.gov.tr/arms-control-and-disarmament.en.mfa $>$.

60. "Working Paper Submitted by Belgium, Lithuania, the Netherlands, Norway, Poland, Spain and Turkey for Consideration at the 2010 Review Conference of the States Parties to the Treaty on the NonProliferation of Nuclear Weapons," p. 6.

61. Ibid.

62. 2010 NPR, p. 3.

63. Mustafa Kibaroglu, "National Counter Terrorism Law Case Studies: Turkey," in Tyler Rauert, ed., Lifting the Fog of Law: Legal Regimes to Combat Terrorism in Near East and South Asia (Washington, DC: National Defense University, forthcoming).

64. Author's not-for-attribution interview with Turkish military official, Ankara, March 2010, Ankara.

65. Author's not-for-attribution interview with Turkish government official, Ankara, March 2010.

66. Guy Roberts, "Preventing Weapons of Mass Destruction Terrorism: Building International Partnership to meet the Challenge," in Osman Aytac and Mustafa Kibaroglu, eds., Defense Against Weapons of Mass Destruction Terrorism (Amsterdam: IOS Press, 2009), p. 9.

67. Peter Zimmerman, "Do We Really Need to Worry? Some Reflections on the Threat of Nuclear Terrorism," Defence Against Terrorism Review 2 (Fall 2009), pp. 1-14.

68. Kibaroglu and Caglar, "Implications of a Nuclear Iran for Turkey," pp. 59-80.

69. Ibrahim Kalin, chief foreign policy adviser to Prime Minister Erdogan, reportedly said that Turkey won't necessarily fight to keep the US tactical deployment: "As for his own personal opinion, Kalin said, Turkey 'would not insist' that NATO retain forward-deployed nuclear weapons. Conventional forces are sufficient, he added, to meet Turkish security needs." See Jeffrey Lewis, "Official: Ankara Doesn't Need NATO Nukes," ArmsControlWonk.com, December 8, 2009, <lewis.armscontrolwonk.com/ archive/2561/official-ankara-would-not-insist-on-nato-nukes $>$.

70. Author's not-for-attribution interview with high-ranking Turkish diplomat, Ankara, July 2010. 